\title{
Влияние результатов генотипирования в подборе терапии первичного психоза с суицидальной попыткой
}

\author{
Кулакова Н. Л.', Абдусаламова О. А.² \\ 1 - БУ «Республиканская психиатрическая больница» Минздрава Чувашии, Россия, Чебоксары \\ 2 - ФГБОУ ВО «Чувашский государственный университет им. И. Н. Ульянова», Россия, Чебоксары
}

Ключевые слова: генотипирование; первичный психоз; суицидальные мысли; фармакогенетическое тестирование; ген CYP2D6

\begin{abstract}
Для цитирования:
Кулакова Н.Л., Абдусаламова О.А. Влияние результатов генотипирования в подборе терапии первичного психоза с суицидальной попыткой // Фармакогенетика и фармакогеномика. 2020;(2):35. (In Russ). DOI: 10.37489/25880527-2020-2-35
\end{abstract}

Описание пациента. Пациент В., 23 года, доставлен в психиатрическую больницу впервые в жизни в связи с суицидальной попыткой на фоне болезненных переживаний. До госпитализации психиатрами не наблюдался. Раннее развитие без особенностей. После окончания школы поступил в колледж, где отучился на «электрика», отслужил в армии год. По характеру с детства был тихим, спокойным, самостоятельным. Психическое состояние изменилось с начала 2020 года, когда начал ощущать слежку по телефону, беспричинно уволился с работы, начал замыкаться в себе. Однократно обращался к психотерапевту, который амбулаторно назначил квентиакс в дозе 200 мг/сут. Однако состояние пациента ухудшалось, начал высказывать, что его преследуют «воры в законе», что его хотят убить, в результате чего нанёс себе колото-резаную рану в шею. Стационарно пролечился в хирургическом отделении, где начал испытывать вербальные галлюцинации угрожающего характера. При поступлении был крайне тревожен, на месте не удерживался, боялся слежки, активно высказывал бредовые идеи воздействия и преследования, коррекции не поддавался. Был выставлен диагноз: «Острое полиморфное психотическое расстройство с симптомами шизофрении» F 23.1.

Тип вмешательства. Начал получать раствор галоперидола в дозе 15 мг/сут с раствором бромдигидрохлорфенилбензодиазепина внутривенно капельно. На фоне терапии оставался подозрительным, тревожным, сохранялись суицидальные мысли, редукции бредовых идей не наблюдалось, в связи с чем увеличена доза галоперидола до 20 мг/сут, присоединен клозапин в дозе 25 мг/сут, с постепенным наращиванием до 100 мг/сут, затем был переведён на приём трифлуоперазина 20 мг/сут в комбинации с клозапином 100 мг/сут. Переносимость препаратов оставалась удовлетворительной, однако явной положительной динамики не наблюдалось.
Показания к персонализации. В связи с неэффективностью терапии нейролептиками в обычных дозах, отсутствием ремиссии было решено применить персонализированный подход к выбору терапии.

Тип персонализации. Выполнено молекулярно-генетическое исследование с целью определения генотипа гена CYP2D6 с помошью ПЦР в режиме реального времени. Ген CYP2D6 ответственен за фармакодинамику и фармакокинетику лекарственных средств, в том числе и нейролептиков, известно более 80 его аллелей. Препараты, метаболизируемые CYP2D6, имеют низкий терапевтический индекс, т. е. разница между дозой, необходимой для достижения лечебного эффекта и токсической дозой невелика.

В данном случае пациент оказался носителем CYP2D6*2, одним из лиц, имеющих мутацию с высокой метаболизирующей активностью.

Изменения после персонализации. У носителей CYP2D6*2 из-за ускоренного метаболизма лекарственных средств для достижения терапевтического эффекта доза лекарственного средства должна быть выше, чем для активных метаболизаторов.

На основе результатов генотипирования пациента было предложено увеличить дозу трифлуоперазина до максимальной суточной дозы - 40 мг/сут в комбинации с клозапином 100 мг/сут.

Динамика. В психическом состоянии пациента наметилась положительная динамика: отметил снижение тревоги и страха, появилась критика к бредовым высказываниям про преследование, начал лучше спать. Переносимость лекарственных препаратов оставалась удовлетворительной.

Заключение. Фармакогенетическое тестирование гена CYP2D6 открывает дополнительные возможности для персонализированного подбора терапии у пациентов с неэффективностью обычных доз нейролептиков, позволяет глубже изучить проблему индивидуализации терапии в психиатрической практике. 